\title{
Fluoroscopic cervical epidural injections in chronic axial or disc-related neck pain without disc herniation, facet joint pain, or radiculitis
}

This article was published in the following Dove Press journal: Journal of Pain Research

3 July 2012

Number of times this article has been viewed

\section{Laxmaiah Manchikanti \\ Kimberly A Cash \\ Vidyasagar Pampati \\ Yogesh Malla}

Pain Management Center of Paducah, Paducah, KY, USA
Correspondence: Laxmaiah Manchikanti 283I Lone Oak Road, Paducah, KY 42003, USA

$\mathrm{Tel}+\mid 2705548373$ ext I0 I

Fax + I 2705548987

Email drlm@thepainmd.com
Background: While chronic neck pain is a common problem in the adult population, with a typical 12-month prevalence of $30 \%-50 \%$, there is a lack of consensus regarding its causes and treatment. Despite limited evidence, cervical epidural injections are one of the commonly performed nonsurgical interventions in the management of chronic neck pain.

Methods: A randomized, double-blind, active, controlled trial was conducted to evaluate the effectiveness of cervical interlaminar epidural injections of local anesthetic with or without steroids for the management of chronic neck pain with or without upper extremity pain in patients without disc herniation, radiculitis, or facet joint pain.

Results: One hundred and twenty patients without disc herniation or radiculitis and negative for facet joint pain by means of controlled diagnostic medial branch blocks were randomly assigned to one of two treatment groups, ie, injection of local anesthetic only (group 1) or local anesthetic mixed with nonparticulate betamethasone (group 2). The primary outcome of significant pain relief and improvement in functional status $(\geq 50 \%)$ was demonstrated in $72 \%$ of group 1 and $68 \%$ of group 2 . The overall average number of procedures per year was 3.6 in both groups with an average total relief per year of 37-39 weeks in the successful group over a period of 52 weeks.

Conclusion: Cervical interlaminar epidural injections of local anesthetic with or without steroids may be effective in patients with chronic function-limiting discogenic or axial pain.

Keywords: chronic neck pain, cervical disc herniation, cervical discogenic pain, cervical epidural injections, epidural steroids, local anesthetics

\section{Introduction}

Chronic pain in the US has reached crisis levels, with an explosion of diagnostic and therapeutic measures. ${ }^{1}$ Chronic spinal pain is common in the general adult population, with low back and neck pain constituting the majority of the disorders. ${ }^{2-6}$ All modalities of treatment, including cervical spine surgery and cervical epidural injections, have risen dramatically over the past two decades. ${ }^{3,7-17}$ Studies of the prevalence of chronic neck pain and its impact on general health have shown that $14 \%$ of patients report grade II-IV neck pain, with a high pain intensity leading to disability, with grade 0 referring to no neck pain; grade I representing pain of low intensity and few activity limitations; grade II with pain of high intensity, but few activity limitations; grade III with pain of high intensity and high levels of disability associated with moderate limitations in activities; and grade IV referring to pain with high levels of disability and several activity limitations. ${ }^{5,6}$ Further, chronic recurrent neck pain is a common problem in the adult population, with a typical 12 -month prevalence of $30 \%-50 \%{ }^{2,4,16}$ 
Apart from cervical disc herniation, cervical facet joint and discogenic pain are the common causes, resulting in chronic mechanical neck pain with or without upper extremity

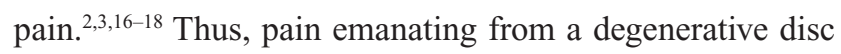
may result in discogenic pain secondary to chemical irritation or predominantly axial pain secondary to internal disc disruption. ${ }^{19-21}$ Axial neck pain may be related to either a disc or facet joint, or be musculoligamentous. However, there is a lack of consensus regarding the causes and treatment of chronic neck pain without disc herniation and radiculitis.

Among the various treatments available for managing axial discogenic pain, epidural injections are one of the most common nonsurgical interventions..$^{3,16,22-28}$ In general, cervical epidural injections are not recommended for axial neck pain, but they are considered to be reasonable in disc herniation with radiculitis and spinal stenosis. The evidence for cervical epidural injections in disc herniation and radiculitis, though debated, is moderate. ${ }^{3}$ The evidence for epidural injection in axial discogenic pain is based on a single preliminary report of discogenic neck pain after excluding cervical facet joint pain in patients without disc herniation or radiculitis. ${ }^{23}$ In this trial, 70 patients were included, with 35 patients receiving local anesthetics only and the other 35 receiving local anesthetics with nonparticulate betamethasone. The results showed significant pain relief $(\geq 50 \%)$ in $80 \%$ of the patients in both groups, along with improvement in functional status ( $\geq 50 \%$ ) in $69 \%$ in group 1 (receiving local anesthetic only) and $80 \%$ in group 2 (also receiving steroids). In fact, the results of this preliminary evaluation were similar to those for disc herniation in the cervical spine, ${ }^{22}$ lumbar spine, ${ }^{29,30}$ thoracic spine, ${ }^{31}$ and discogenic pain in the lumbar spine, ${ }^{32,33}$ and superior to the results for spinal stenosis and post surgery syndrome in the lumbar and cervical spine. ${ }^{24,25,34-36}$

The underlying mechanism of action of epidurally administered local anesthetics and steroids is not clear, and is believed to be due to the anti-inflammatory properties of corticosteroids, but the evidence also indicates that local anesthetics may be as effective as steroids in managing spinal pain of various origins. ${ }^{22-25,29-39}$ Based on the clinical and experimental evidence, it appears that local anesthetics and steroids may provide long-term relief. ${ }^{40-47}$

This study was undertaken to evaluate the role of cervical interlaminar epidural injections of local anesthetics with or without steroids in patients with chronic, function-limiting neck pain with or without upper extremity pain secondary to discogenic pain without disc herniation, radiculitis, or facet joint pain. This report consists of the results of
120 patients at one-year follow-up, and is a continuation of a published preliminary report. ${ }^{23}$

\section{Materials and methods}

The study was conducted in an interventional pain management practice, ie, a specialty referral center, in a private practice setting in the United States, based on Consolidated Standards of Reporting Trials guidelines. ${ }^{48}$ The study protocol was approved by the local institutional review board and was registered with the US Clinical Trial Registry (NCT01071369). This study was conducted with the internal resources of the practice without any external funding either from industry or from elsewhere. All ethical guidelines were followed.

\section{Participants}

Patients were recruited from new patients presenting for interventional pain management. All patients were provided with the IRB-approved protocol and informed consent which described in detail all aspects of the study and withdrawal process.

\section{Interventions}

The patients were assigned to one of two groups, ie, group 1, in which patients received cervical interlaminar epidural injections of local anesthetic (lidocaine $0.5 \%, 5 \mathrm{~mL}$ ), and group 2, in which patients received cervical interlaminar epidural injections comprising $4 \mathrm{~mL}$ of lidocaine $0.5 \%$ mixed with $1 \mathrm{~mL}$ or $6 \mathrm{mg}$ of nonparticulate betamethasone for a total of $5 \mathrm{~mL}$ of injectate.

\section{Pre-enrollment evaluation}

Initially, all patients with axial pain underwent controlled comparative local anesthetic blocks to exclude facet joint pain. ${ }^{49,50}$ In addition, patient demographic data, medical and surgical history with coexisting disease(s), radiologic investigations, physical examination, pain rating scores using the Numeric Rating Scale (NRS), work status, opioid intake, and functional status assessment by the Neck Disability Index (NDI) were also collected.

\section{Inclusion criteria}

Inclusion criteria were: lack of a diagnosis of cervical facet joint pain by means of controlled, comparative local anesthetic blocks and an absence of cervical disc herniation or radiculitis; at least 18 years of age; a history of chronic function-limiting neck and upper extremity pain of at least 6 months duration; and ability to understand the study 
protocol and provide voluntary, written, informed consent. In addition, patients should have failed conservative management, including, but not limited to, physical therapy, medical therapy, and a structured exercise program.

\section{Exclusion criteria}

Exclusion criteria were: presence of cervical disc herniation; radiculitis secondary to spinal stenosis without disc herniation; uncontrollable or unstable opioid use; uncontrolled psychiatric disorders; uncontrolled medical illness, either acute or chronic; any conditions that could interfere with the interpretation of the outcome assessments; pregnant or lactating women; and a history or potential for adverse reaction(s) to local anesthetics or steroids.

\section{Description of interventions}

Diagnostic facet joint nerve blocks were performed on two different occasions utilizing short-acting and long-acting local anesthetics, specifically $0.5 \mathrm{~mL}$ of $1 \%$ preservative-free lidocaine on the first occasion, and $0.25 \%$ preservative-free bupivacaine on the second occasion. The patient's response was considered positive if pain relief lasted more than two hours following lidocaine injection and lasted at least three hours or more or longer than the duration of relief with lidocaine when bupivacaine was used, plus the ability to perform previously painful movements.

Cervical interlaminar epidural procedures were performed under fluoroscopy in a sterile operating room with patients in the prone position, appropriate monitoring, and intravenous access and sedation as medically necessary by one physician (LM). The epidural space was identified using the loss of resistance technique under fluoroscopic visualization. The epidural space was entered between $\mathrm{C} 7-\mathrm{T} 1$ and $\mathrm{C} 5-\mathrm{C} 6$ with confirmation by injection of nonionic contrast medium. Following confirmation of the epidural space, we performed clear solution injections of $5 \mathrm{~mL}$ of preservative-free lidocaine hydrochloride $0.5 \%$ or $4 \mathrm{~mL}$ of preservative-free lidocaine mixed with $6 \mathrm{mg}$ of nonparticulate betamethasone.

\section{Additional interventions}

Repeat cervical epidural injections were provided when increased levels of pain were reported with deteriorating relief below $50 \%$. A patient was unblinded if requested or if an emergency situation arose. Patients who were nonresponsive and continued with conservative management were followed without further epidural injections and medical management, unless they requested unblinding. There was no specific physical therapy, occupational therapy, bracing, or further interventions offered other than the study intervention. All patients continued drug therapy, exercise programs, as well as their work.

\section{Objectives and outcomes}

The study was designed to evaluate objectively the effectiveness of cervical epidural injections with or without steroids for managing chronic neck and upper extremity pain secondary to discogenic pain without disc herniation, radiculitis, or facet joint pain. Outcomes measured included NRS, NDI, work status, and opioid intake in terms of morphine equivalents, assessed at baseline and at 3, 6, and 12 months following treatment. The primary outcome was defined as at least $50 \%$ pain relief associated with 50\% improvement in NDI. The NRS and NDI have been shown to be valid and reliable in patients with mechanical neck pain. ${ }^{51-55}$ Opioid intake was evaluated with conversion to morphine equivalents. ${ }^{56}$ Patients unemployed or employed on a part-time basis with limited or no employment due to pain were classified as employable. Patients who chose not to work, were retired, or were homemakers (not working, but not due to pain) were not considered to be in the employment pool.

\section{Randomization and blinding}

From a total of 120 patients, 60 were randomly assigned into each group. Randomization was performed by computergenerated random allocations sequence by, simple randomization. The operating room nurse assisting with the procedure randomized the patients and prepared the drugs appropriately to ensure allocation concealment. The patients and the physician were blinded to group assignment. Both solutions were clear and it was impossible to identify if the steroid had been added or not. Further, blinding was also assured by mixing the patients with other patients receiving routine treatment and not informing the physician performing the procedure of the inclusion of the patients in the study. All the patients chosen for one-year follow-up were selected by a statistician who did not provide patient care. The unblinding results were not disclosed to either the treating physician, other health care providers, or patients. Thus, the nature of blinding was not interrupted.

\section{Statistical methods}

Sample size was calculated based on significant pain relief. Considering a 0.05 two-sided significance level, a power of $80 \%$, and an allocation ratio of 1:1, 55 patients in each group were estimated to be necessary ${ }^{57}$ allowing for a $10 \%$ attrition/ noncompliance rate, 60 patients were required. 
Statistical analysis included the Chi-squared statistic, Fisher exact test, $t$-test, and paired $t$-test. Results were considered statistically significant if the $P$ value was less than 0.05 . The Chi-squared statistic was used to test the differences in proportions. Fisher exact test was used wherever the expected value was less than 5 ; a paired $t$-test was used to compare the pretreatment and post-treatment results of average pain scores and NDI measurements at baseline versus 3, 6, and 12 months. For comparison of mean scores between groups, the $t$-test was performed. An intent-to-treat-analysis was performed. Either the last follow-up data or initial data were utilized for patients who dropped out of the study and for whom no other data were available. Sensitivity analysis was performed utilizing best case, worst case, and last follow-up score scenarios.
Figure 1 illustrates the patient flow. Recruitment lasted from August 2007 through June 2010. Baseline demographic and clinical characteristics for each group are summarized in Table 1. Table 2 shows the NRS scores and the proportion of patients with $\geq 50 \%$ pain relief in each category. Functional assessment results assessed by the NDI are shown in Table 3. Figure 2 shows the pain relief and functional status assessment in all patients, including both failed and successful patients.

\section{Characteristics of the therapeutic procedure}

The characteristics of the therapeutic procedure are summarized in Table 4. Epidural entry was in the vertebral interspaces as follows: $33 \%$ between $\mathrm{C} 7$ and $\mathrm{T} 1,58 \%$ between $\mathrm{C} 6$ and $\mathrm{C} 7$, and 9\% between $\mathrm{C} 5$ and C6. No signifi-

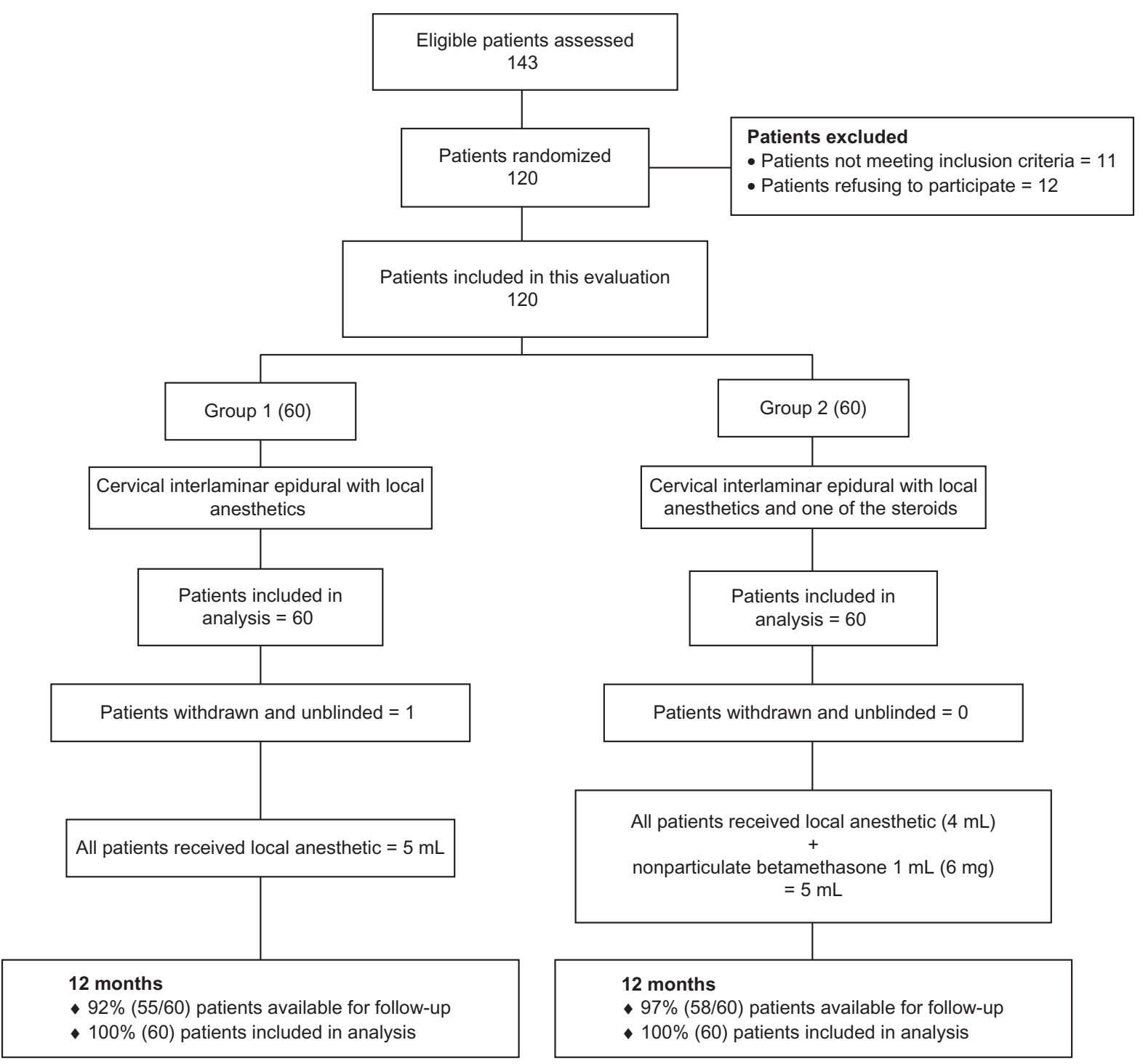

Figure I Schematic presentation of patient flow at one-year follow up of I 20 patients. 
Table I Baseline demographic characteristics

\begin{tabular}{|c|c|c|c|}
\hline & $\begin{array}{l}\text { Group I } \\
(n=60)\end{array}$ & $\begin{array}{l}\text { Group } 2 \\
(n=60)\end{array}$ & $P$ value \\
\hline \multicolumn{4}{|l|}{ Gender } \\
\hline Male & $25 \%(15)$ & $32 \%(19)$ & 0.544 \\
\hline Female & $75 \%(45)$ & $68 \%(4 I)$ & \\
\hline \multicolumn{4}{|l|}{ Age } \\
\hline Mean \pm SD & $44.5 \pm 12.6$ & $41.8 \pm 11.6$ & 0.235 \\
\hline \multicolumn{4}{|l|}{ Weight } \\
\hline Mean \pm SD & $183.6 \pm 57.5$ & $164.7 \pm 39.3$ & 0.038 \\
\hline \multicolumn{4}{|l|}{ Height } \\
\hline Mean $\pm S D$ & $65.6 \pm 3.0$ & $66.4 \pm 3.5$ & 0.184 \\
\hline \multicolumn{4}{|l|}{ Duration of pain (months) } \\
\hline Mean \pm SD & $100.3 \pm 94.3$ & $95.8 \pm 95.7$ & 0.794 \\
\hline \multicolumn{4}{|l|}{ Onset of pain } \\
\hline Gradual & $58 \%(35)$ & $47 \%(28)$ & 0.273 \\
\hline Injury & $42 \%(25)$ & $53 \%(32)$ & \\
\hline \multicolumn{4}{|l|}{ Neck pain distribution } \\
\hline Neck pain only & $33 \%(20)$ & $43 \%(26)$ & 0.653 \\
\hline $\begin{array}{l}\text { Neck pain worse than } \\
\text { upper extremity }\end{array}$ & $45 \%(27)$ & $37 \%(22)$ & \\
\hline $\begin{array}{l}\text { Upper extremity worse } \\
\text { than neck pain }\end{array}$ & $3 \%(2)$ & $2 \%(I)$ & \\
\hline Both equal & $18 \%(11)$ & $18 \%(I I)$ & \\
\hline \multicolumn{4}{|l|}{ Numeric Rating Scale } \\
\hline Mean \pm SD & $7.9 \pm 0.9$ & $7.6 \pm 0.8$ & 0.074 \\
\hline \multicolumn{4}{|l|}{ Neck Disability Index } \\
\hline Mean \pm SD & $30.2 \pm 4.7$ & $28.6 \pm 7.2$ & 0.164 \\
\hline
\end{tabular}

Abbreviation: SD, standard deviation.

cant differences were noted in average relief per year; in group 1, the average relief was for $36.4 \pm 15.9$ weeks and in group 2 it was $34.8 \pm 16.1$ weeks. The total number of injections per year were $3.6 \pm 1.1$ in group 1 and $3.6 \pm 1.0$ in group 2. However, when patients were separated into successful and failed groups, the total number of injections per year was $3.7 \pm 0.9$ for both successful groups, with total relief for $39.2 \pm 13.2$ weeks in group 1 and for $37.3 \pm 13.7$ weeks in group 2. In contrast, total relief was for $5.2 \pm 8.4$ and for $0.8 \pm 1.0$ weeks in the failed groups. Epidurals were consid-

Table 2 Characteristics of pain relief on Numeric Rating Scale and proportion of patients with significant relief

\begin{tabular}{lccc}
\hline $\begin{array}{l}\text { Numeric } \\
\text { rating score }\end{array}$ & $\begin{array}{l}\text { Group I } \\
(\mathbf{n}=\mathbf{6 0})\end{array}$ & $\begin{array}{l}\text { Group 2 } \\
\mathbf{( n = 6 0 )}\end{array}$ & P value \\
\cline { 2 - 3 } & Mean \pm SD & Mean \pm SD & \\
\hline Baseline & $7.9 \pm 0.9$ & $7.6 \pm 0.8$ & 0.074 \\
3 months & $3.7^{*} \pm 1.4(73 \%)$ & $3.3^{*} \pm 1.0(85 \%)$ & 0.055 \\
6 months & $3.6^{*} \pm 1.4(78 \%)$ & $3.5^{*} \pm 1.3(77 \%)$ & 0.679 \\
I2 months & $3.7^{*} \pm 1.3(80 \%)$ & $3.6^{*} \pm 1.4(73 \%)$ & 0.946 \\
\hline
\end{tabular}

Notes: Percentages in parentheses indicate proportion of participants with significant relief $(\geq 50 \%$ reduction in Numeric Rating Scale from baseline). *Significant difference versus baseline value $(P<0.05)$.

Abbreviation: SD, standard deviation.
Table 3 Illustration of functional assessment scores by Neck Disability Index and proportion of patients with significant ( $\geq 50 \%$ ) improvement

\begin{tabular}{llll}
\hline $\begin{array}{l}\text { Neck Disability } \\
\text { Index }\end{array}$ & $\begin{array}{l}\text { Group I } \\
(\mathbf{n}=\mathbf{6 0})\end{array}$ & $\begin{array}{l}\text { Group 2 } \\
(\mathbf{n}=\mathbf{6 0})\end{array}$ & P value \\
\cline { 2 - 3 } & Mean \pm SD & Mean \pm SD & \\
\hline Baseline & $30.2 \pm 4.7$ & $28.6 \pm 7.2$ & 0.164 \\
3 months & $15.5^{*} \pm 6.0(70 \%)$ & $13.7^{*} \pm 5.4(78 \%)$ & 0.082 \\
6 months & $15.0^{*} \pm 5.6(68 \%)$ & $14.2^{*} \pm 6.1(73 \%)$ & 0.464 \\
I2 months & $14.6^{*} \pm 5.8(73 \%)$ & $14.4^{*} \pm 6.5(68 \%)$ & 0.871 \\
\hline
\end{tabular}

Notes: Percentages in parenthesis indicate proportion of patients with significant improvement of NDI scores from baseline ( $\geq 50 \%)$. *Significant difference versus baseline value $(P<0.00 I)$.

ered to be successful if a patient obtained consistent relief with two initial injections for at least 3 weeks. All others were considered as failures.

\section{Employment characteristics}

Table 5 demonstrates employment characteristics in both groups. Among the patients eligible for employment, the total number of employed changed from 10 at baseline to 17 at the end of 12 months in group 1, and changed from 19 to 21 in group 2, representing a significant increase from $48 \%$ to $77 \%$ in group 1 and a nonsignificant increase from $66 \%$ to $75 \%$ in group 2 .

\section{Opioid intake}

Table 6 illustrates opioid intake characteristics.

\section{Weight changes}

There were no differences in change (gain or loss) in body weight from baseline in both groups (Table 7) even though there was a significant difference at baseline.

\section{Adverse events}

Of the 434 cervical epidural procedures performed, one subarachnoid puncture was reported. Nerve root irritation was observed in three patients without long-term sequelae. All patients experiencing nerve root irritation, even though transient, were given dexamethasone $8 \mathrm{mg}$ intravenously.

\section{Discussion}

This report of the one-year follow-up of a randomized, active controlled trial of 120 patients with axial or discogenic neck pain without evidence of facet joint pain demonstrates significant improvement, with improvement in pain relief and functional status in $72 \%$ of patients in group 1 who received local anesthetic only and in $68 \%$ of patients in group 2 who 


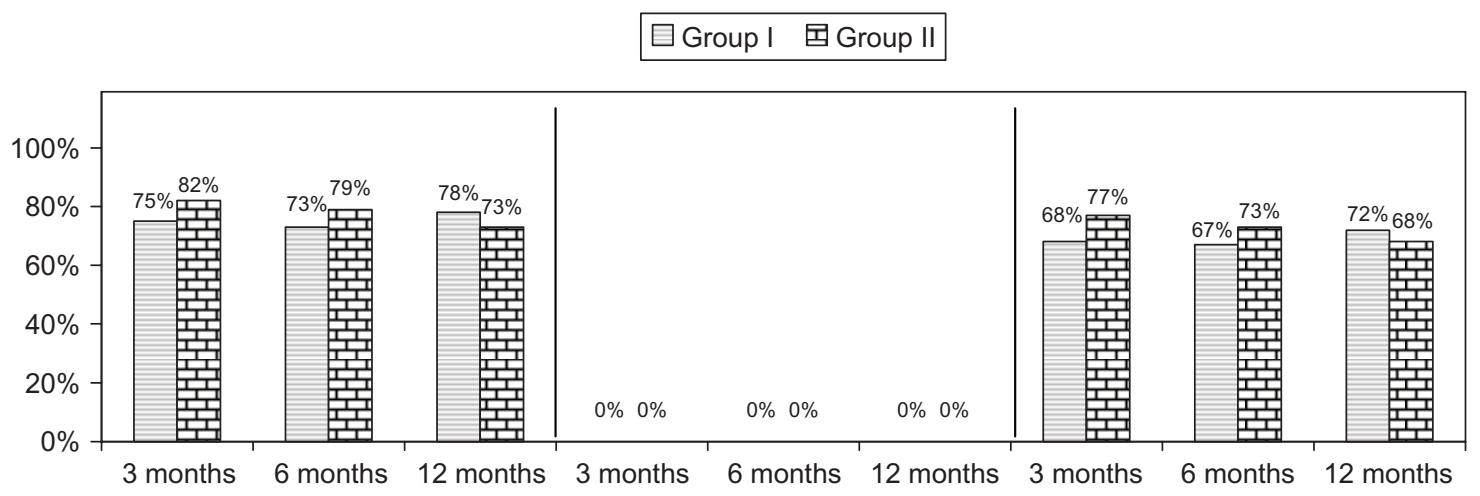

Successful group

Failed group

All patients

Figure 2 Proportion of patients with significant reduction in Numeric Rating Scale and Neck Disability Index ( $\geq 50 \%$ reduction from baseline).

received local anesthetics and steroids. In the successful group, significant improvement was seen in $78 \%$ who received local anesthetic only, whereas in the group who also received steroids, the improvement was $73 \%$. Overall, the average number of procedures per year was 3 to 4 , with an average duration of total relief per year of $36.4 \pm 15.9$ weeks in group 1 and $34.8 \pm 16.1$ weeks in group 2, over a period of 52 weeks. Opioid intake was significantly reduced in group 1 from baseline. In addition, employment also increased significantly in group 1, but there was also a nonsignificant increase in group 2. Regarding employment characteristics, it is difficult to differentiate between those seeking work during a recession and those who are unable to work. Further, the number of patients unemployed due to pain decreased from 6 to 2 in group 1 and 6 to 4 in group 2.
There was no significant difference among the patients receiving steroids and those who did not. Both groups showed similar significant improvement. The results were also similar to both the preliminary results of this study and to the results of a similar study ${ }^{32,33}$ in the lumbar spine. There were no significant differences noted among the groups, whether they were receiving steroids or not, with respect to weight.

There is a paucity of literature with respect to epidural injections, specifically in managing axial or discogenic neck pain. There have been only two systematic reviews. ${ }^{3,58}$ However, these reviews included only studies evaluating cervical epidural injections in disc herniation and radiculitis. Further, these were also performed under fluoroscopy. Since the publication of these systematic reviews, multiple studies have been published evaluating the role of cervical epidural

Table 4 Therapeutic procedural characteristics with procedural frequency, average relief per procedure, and average total relief in weeks over a period of one year

\begin{tabular}{|c|c|c|c|c|c|c|}
\hline & \multicolumn{2}{|c|}{ Successful patients } & \multicolumn{2}{|c|}{ Failed patients } & \multicolumn{2}{|l|}{ Combined } \\
\hline & $\begin{array}{l}\text { Group I } \\
(n=55)\end{array}$ & $\begin{array}{l}\text { Group } 2 \\
(n=56)\end{array}$ & $\begin{array}{l}\text { Group I } \\
(n=5)\end{array}$ & $\begin{array}{l}\text { Group } 2 \\
(n=4)\end{array}$ & $\begin{array}{l}\text { Group I } \\
(n=60)\end{array}$ & $\begin{array}{l}\text { Group } 2 \\
(n=60)\end{array}$ \\
\hline Ist procedure relief & $7.3 \pm 5.3(55)$ & $7.7 \pm 7.9(56)$ & $I . I \pm I . I(5)$ & $0.1 \pm 0.1(4)$ & $6.7 \pm 5.4(60)$ & $7.2 \pm 7.8(60)$ \\
\hline 2nd procedure relief & $|I .0 \pm 5|.(55)$ & $9.7 \pm 5.7(54)$ & $1.0 \pm 1.0(3)$ & $0.3 \pm 0.6(3)$ & $10.5 \pm 5.4(58)$ & $9.2 \pm 6.0(57)$ \\
\hline $3 r d$ procedure relief & $13.4 \pm 7.3(48)$ & $11.5 \pm 4.3(50)$ & $2.6 \pm 3.3(2)$ & $1.0 \pm 0.0(2)$ & $13.0 \pm 7.5(50)$ & $1 \mathrm{I} .1 \pm 4.7(52)$ \\
\hline 4th procedure relief & $14.0 \pm 7.1(35)$ & $11.9 \pm 4.6(40)$ & $13.0(I)$ & 0 & $14.0 \pm 7.0(36)$ & $11.9 \pm 4.6(40)$ \\
\hline 5th procedure relief & $11.6 \pm 3.7(12)$ & $12.5 \pm 1.5(8)$ & $0.0(I)$ & 0 & $10.7 \pm 4.8(13)$ & $12.5 \pm 1.5(8)$ \\
\hline $\begin{array}{l}\text { Average number of } \\
\text { procedures for one year }\end{array}$ & $3.7 \pm 0.9(55)$ & $3.7 \pm 0.9(56)$ & $2.4 \pm 1.7(5)$ & $2.2 \pm 1.0(4)$ & $3.6 \pm I . I(60)$ & $3.6 \pm 1.0(60)$ \\
\hline $\begin{array}{l}\text { Average relief per } \\
\text { procedure for initial two } \\
\text { procedures in weeks }\end{array}$ & $9.1 \pm 5.5(110)$ & $8.7 \pm 7.0(110)$ & $1.1 \pm 1.0(8)$ & $0.2 \pm 0.4(7)$ & $8.6 \pm 5.7(118)$ & $8.2 \pm 7.0(117)$ \\
\hline $\begin{array}{l}\text { Average relief per procedure } \\
\text { after initial two procedures }\end{array}$ & $13.4^{\#} \pm 6.9(95)$ & $11.8 \pm 4.2(98)$ & $4.6 \pm 6.1(4)$ & $1.0 \pm 0(2)$ & $13.1 \pm 7.0$ (99) & $11.5 \pm 4.5(100)$ \\
\hline Average relief per procedure & $\mathrm{II} . \mathrm{I} \pm 6.5(205)$ & $10.1 \pm 6.0(208)$ & $2.2 \pm 3.7(12)$ & $0.4 \pm 0.5(9)$ & $10.6 \pm 6.7(217)$ & $9.7 \pm 6.2(217)$ \\
\hline $\begin{array}{l}\text { Average total relief for } \\
\text { one year (weeks) }\end{array}$ & $39.2 \pm 13.2(55)$ & $37.3 \pm 13.7(56)$ & $5.2 \pm 8.4(5)$ & $0.8 \pm 1.0(4)$ & $36.4 \pm 15.9(60)$ & $34.8 \pm 16.1(60)$ \\
\hline
\end{tabular}

Notes: Number in parenthesis indicates number of patients. "Significant difference versus group $2(P<0.05)$. 
Table 5 Employment characteristics

\begin{tabular}{|c|c|c|c|c|}
\hline \multirow[t]{2}{*}{ Employment status } & \multicolumn{2}{|l|}{ Group I } & \multicolumn{2}{|l|}{ Group 2} \\
\hline & Baseline & 12 months & Baseline & 12 months \\
\hline Employed part-time & 8 & 5 & 5 & 4 \\
\hline Employed full-time & 2 & 12 & 14 & 17 \\
\hline Unemployed (due to pain) & 6 & 2 & 6 & 4 \\
\hline Not working & 5 & 3 & 4 & 3 \\
\hline Total employed & $10(48 \%)$ & 17 (77\%) & $19(66 \%)$ & 21 (75\%) \\
\hline $\begin{array}{l}\text { Percentage of change in employment } \\
\text { status from baseline }\end{array}$ & & $29 \% *$ & & $9 \%$ \\
\hline Eligible for employment & 21 & 22 & 29 & 28 \\
\hline Housewife & 37 & 36 & 27 & 28 \\
\hline Disabled & 2 & 2 & 2 & 2 \\
\hline Retired & 0 & 0 & 2 & 2 \\
\hline Total number of patients & 60 & 60 & 60 & 60 \\
\hline
\end{tabular}

Note: *Significant difference versus baseline value $(P<0.05)$.

injections in various conditions performed with fluoroscopy. ${ }^{22-25}$ The results of this evaluation are similar to the results in disc herniation, either in the cervical or lumbar spine..$^{29,30,32-36}$ Overall, this study also provides insight into successful or failed groups based on positive procedures, even though the proportion of patients in the failed group was low, with only five in group 1 and four in group 2 out of 60 patients in each group. Overall, successful patients fared better even though there was no significant difference.

This trial has multiple strengths and limitations. The strengths include it being a practical clinical trial with a fairly large number of patients with an active-control design performed under fluoroscopy and repeat injections provided only upon return of pain and deterioration of functional status. In an era of comparative effectiveness and evidence-based medicine, ${ }^{59-63}$ the current study, though limited to a single center, provides evidence generalizable to contemporary interventional pain management settings. Patient selection was undertaken with great sensitivity, including only patients with axial neck pain but without facet joint pain. Thus, it may be considered that the study meets the criteria for pragmatic or practical clinical trials with an active-control group instead of a placebo group and for measuring effectiveness,

Table 6 Opioid intake (morphine equivalence $\mathrm{mg}$ )

\begin{tabular}{lcll}
\hline $\begin{array}{l}\text { Opioid intake } \\
\text { (Morphine }\end{array}$ & $\begin{array}{l}\text { Group I } \\
(\mathbf{n}=\mathbf{6 0})\end{array}$ & $\begin{array}{l}\text { Group 2 } \\
(\mathbf{n}=\mathbf{6 0})\end{array}$ & P value \\
\cline { 2 - 3 } equivalence mg) & Mean \pm SD & Mean \pm SD & \\
\hline Baseline & $47.0 \pm 35.0$ & $39.1 \pm 27.1$ & 0.171 \\
3 months & $37.1^{*} \pm 21.2$ & $33.7 \pm 22.0$ & 0.386 \\
6 months & $36.8^{*} \pm 21.0$ & $33.8 \pm 22.0$ & 0.451 \\
I2 months & $36.9^{*} \pm 20.9$ & $34.7 \pm 23.5$ & 0.579 \\
\hline
\end{tabular}

Note: *Significant difference versus baseline value $(P<0.05)$.

Abbreviation: SD, standard deviation. which is more appropriate than explanatory trials that measure efficacy. ${ }^{55,64-67}$

Limitations include the lack of a placebo group. Having a placebo group has been a controversial issue in interventional pain management and is widely debated. ${ }^{68-74}$ Placebo interventions have been misinterpreted based on the solution injected and the location of the injection, with some even interpreting local anesthetic injection as placebo, not realizing that inactive substances injected into active structures tend to result in various types of effects. ${ }^{74-78}$ Further, the only appropriate placebo design, reported by Ghahreman et al, ${ }^{73}$ showed no significant effect when sodium chloride solution was injected into an inactive structure (injection of an inactive substance into an inactive structure), ie, a true placebo. The other limitation in this study includes the slightly higher weight of the patients in group 1 compared with group 2. However, this is not expected to have caused any variations in outcomes of the study.

The implications of this trial for health care are enormous considering exploding health care costs and the emphasis on comparative effectiveness research and evidence-based medicine. As is well known, studies with appropriate methodology

Table 7 Patterns of weight change

\begin{tabular}{llll}
\hline Weight (Ibs) & $\begin{array}{l}\text { Group I } \\
(\mathbf{n}=\mathbf{6 0})\end{array}$ & $\begin{array}{l}\text { Group 2 } \\
(\mathbf{n}=\mathbf{6 0})\end{array}$ & P value \\
\cline { 2 - 3 } & Mean \pm SD & Mean \pm SD & \\
\hline Weight at beginning & $183.6 \pm 57.5$ & $164.7 \pm 39.3$ & 0.038 \\
Weight at one year & $182.6 \pm 59.7$ & $165.4 \pm 41.8$ & 0.070 \\
Change & $-1.0 \pm 9.7$ & $0.7 \pm 8.8$ & 0.313 \\
\hline Lost weight & $43 \%(26)$ & $38 \%(23)$ & 0.645 \\
No change & $20 \%(12)$ & $17 \%(10)$ & \\
Gained weight & $37 \%(22)$ & $45 \%(27)$ & \\
\hline
\end{tabular}

Abbreviation: SD, standard deviation. 
in practical settings are not only crucial, but are also helpful in promoting, improving the quality of, and curtailing the costs of health care. However, by the same token, the inappropriate provision of any type of intervention, specifically one with substantial expenses, will not only be devoid of any benefit, but will harm the patient and reduce access by depleting resources. Likewise, inappropriately performed evaluations that lead to inaccurate and inappropriate conclusions due to a lack of knowledge or bias may reduce health care expenditure, but will also increase patient suffering, reduce function, increase drug use, and finally impede access to medical care.

\section{Conclusion}

This randomized, double-blind, active-controlled trial of 120 patients with chronic function-limiting axial or discogenic neck pain treated with fluoroscopically guided cervical epidural injections and local anesthetics with or without steroids showed effectiveness in $75 \%$ of patients, with improvement in pain and functional status, requiring an average of 3-4 procedures over a period of one year, with relief for 37-39 weeks over a period of one year in the successful group.

\section{Disclosure}

None of the authors report any competing interests in this work.

\section{References}

1. Pizzo PA, Clark NM. Alleviating suffering 101 - pain relief in the United States. N Engl J Med. 2012;367(3):197-198.

2. Manchikanti L, Singh V, Datta S, Cohen SP, Hirsch JA. Comprehensive review of epidemiology, scope, and impact of spinal pain. Pain Physician. 2009;12(4):E35-E70.

3. Benyamin RM, Singh V, Parr AT, Conn A, Diwan S, Abdi S. Systematic review of the effectiveness of cervical epidurals in the management of chronic neck pain. Pain Physician. 2009;12(1):137-157.

4. Hogg-Johnson S, van der Velde G, Carroll LJ, et al. The burden and determinants of neck pain in the general population: results of the Bone and Joint Decade 2000-2010 task force on neck pain and its associated disorders. Spine (Phila Pa 1976). 2008;33(Suppl 4):S39-S51.

5. Côté P, Cassidy JD, Carroll L. The Saskatchewan health and back pain survey. The prevalence of neck pain and related disability in Saskatchewan adults. Spine (Phila Pa 1976). 1998;23(15):1689-1698.

6. Côté P, Cassidy JD, Carroll LJ, Kristman V. The annual incidence and course of neck pain in the general population: a population-based cohort study. Pain. 2004;112(3):267-273.

7. Manchikanti L, Pampati V, Boswell MV, Smith HS, Hirsch JA. Analysis of the growth of epidural injections and costs in the Medicare population: a comparative evaluation of 1997, 2002, and 2006 data. Pain Physician. 2010;13(3):199-212.

8. Manchikanti L, Pampati V, Singh V, Boswell MV, Smith HS, Hirsch JA. Explosive growth of facet joint interventions in the medicare population in the United States: a comparative evaluation of 1997, 2002, and 2006 data. BMC Health Serv Res. 2010;10:84.

9. Manchikanti L, Ailinani H, Koyyalagunta D, et al. A systematic review of randomized trials of long-term opioid management for chronic noncancer pain. Pain Physician. 2011;14(2):91-121.

10. Manchikanti L, Vallejo R, Manchikanti KN, Benyamin RM, Datta S, Christo PJ. Effectiveness of long-term opioid therapy for chronic noncancer pain. Pain Physician. 2011;14(2):E133-E156.
11. Wang MC, Chan L, Maiman DJ, Kreuter W, Deyo RA. Complications and mortality associated with cervical spine surgery for degenerative disease in the United States. Spine (Phila Pa 1976). 2007;32(3): 342-347.

12. Manchikanti L, Parr AT, Singh V, Fellows B. Ambulatory surgery centers and interventional techniques: a look at long-term survival. Pain Physician. 2011;14(2):E177-E215.

13. Manchikanti L, Fellows B, Ailinani H, Pampati V. Therapeutic use, abuse, and nonmedical use of opioids: a ten-year perspective. Pain Physician. 2010;13(5):401-435.

14. Helgeson MD, Albert TJ. Surgery for failed cervical spine reconstruction. Spine (Phila Pa 1976). 2012;37(5):E323-E327.

15. Patil PG, Turner DA, Pietrobon R. National trends in surgical procedures for degenerative cervical spine disease:1990-2000. Neurosurgery. 2005;57(4):753-758.

16. Manchikanti L, Boswell MV, Singh V, et al. Comprehensive evidencebased guidelines for interventional techniques in the management of chronic spinal pain. Pain Physician. 2009;12(4):699-802.

17. Manchikanti L, Dunbar EE, Wargo BW, Shah RV, Derby R, Cohen SP. Systematic review of cervical discography as a diagnostic test for chronic spinal pain. Pain Physician. 2009;12(2):305-321.

18. Yin $\mathrm{W}$, Bogduk $\mathrm{N}$. The nature of neck pain in a private pain clinic in the United States. Pain Medicine. 2008;9(2):196-203.

19. Lotz JC, Ulrich JA. Innervation, inflammation, and hypermobility may characterize pathologic disc degeneration: review of animal model data. J Bone Joint Surg Am. 2006;88(Suppl 2):76-82.

20. Cloward RB. Cervical discography. Acta Radiol Diagn (Stockh). 1963;1:675-688.

21. Cloward RB. Cervical diskography. A contribution to the etiology and mechanism of neck, shoulder and arm pain. Ann Surg. 1959;150: 1052-1064.

22. Manchikanti L, Cash KA, Pampati V, Wargo BW, Malla Y. The effectiveness of fluoroscopic cervical interlaminar epidural injections in managing chronic cervical disc herniation and radiculitis: preliminary results of a randomized, double-blind, controlled trial. Pain Physician. 2010;13(3):223-236.

23. Manchikanti L, Cash KA, Pampati V, Wargo BW, Malla Y. Cervical epidural injections in chronic discogenic neck pain without disc herniation or radiculitis: preliminary results of a randomized, double-blind, controlled trial. Pain Physician. 2010;13(4):E265-E278.

24. Manchikanti L, Malla Y, Cash KA, McManus CD, Pampati V. Fluoroscopic epidural injections in cervical spinal stenosis: preliminary results of a randomized, double-blind, active control trial. Pain Physician. 2012;15(1):E59-E70.

25. Manchikanti L, Malla Y, Cash KA, McManus CD, Pampati V. Fluoroscopic cervical interlaminar epidural injections in managing chronic pain of cervical post-surgery syndrome: preliminary results of a randomized, double-blind active control trial. Pain Physician. 2012; 15(1):13-26.

26. Stav A, Ovadia L, Sternberg A, Kaadan M, Weksler N. Cervical epidural steroid injection for cervicobrachialgia. Acta Anaesthesiol Scand. 1993;37(6):562-566.

27. Castagnera L, Maurette P, Pointillart V, Vital JM, Erny P, Senegas J. Long term results of cervical epidural steroid injection with and without morphine in chronic cervical radicular pain. Pain. 1994;58(2):239-243.

28. Pasqualucci A, Varrassi G, Braschi A, et al. Epidural local anesthetic plus corticosteroid for the treatment of cervical brachial radicular pain: single injection versus continuous infusion. Clin J Pain. 2007;23(7): $551-557$.

29. Manchikanti L, Singh V, Cash KA, Pampati V, Damron KS, Boswell MV. A randomized, controlled, double-blind trial of fluoroscopic caudal epidural injections in the treatment of lumbar disc herniation and radiculitis. Spine (Phila Pa 1976). 2011;36(23):1897-1905.

30. Manchikanti L, Singh V, Falco FJE, Cash KA, Pampati V. Evaluation of the effectiveness of lumbar interlaminar epidural injections in managing chronic pain of lumbar disc herniation or radiculitis: a randomized, double-blind, controlled trial. Pain Physician. 2010;13(4): 343-355. 
31. Manchikanti L, Cash KA, McManus CD, Pampati V, Benyamin RM. A preliminary report of a randomized double-blind, active controlled trial of fluoroscopic thoracic interlaminar epidural injections in managing chronic thoracic pain. Pain Physician. 2010;13(6):E357-E369.

32. Manchikanti L, Cash KA, McManus CD, Pampati V, Smith HS. One year results of a randomized, double-blind, active controlled trial of fluoroscopic caudal epidural injections with or without steroids in managing chronic discogenic low back pain without disc herniation or radiculitis. Pain Physician. 2011;14(1):25-36.

33. Manchikanti L, Cash KA, McManus CD, Pampati V, Benyamin RM. Preliminary results of a randomized, double-blind, controlled trial of fluoroscopic lumbar interlaminar epidural injections in managing chronic lumbar discogenic pain without disc herniation or radiculitis. Pain Physician. 2010;13(4):E279-E292.

34. Manchikanti L, Cash KA, McManus CD, Pampati V, Abdi S. Preliminary results of randomized, equivalence trial of fluoroscopic caudal epidural injections in managing chronic low back pain: part 4. Spinal stenosis. Pain Physician. 2008;11(6):833-848.

35. Manchikanti L, Cash KA, McManus CD, Damron KS, Pampati V, Falco FJE. Lumbar interlaminar epidural injections in central spinal stenosis: preliminary results of a randomized, double-blind, active control trial. Pain Physician. 2012;15(1):51-63.

36. Manchikanti L, Singh V, Cash KA, Pampati V, Datta S. Preliminary results of randomized, equivalence trial of fluoroscopic caudal epidural injections in managing chronic low back pain: part 3. Post surgery syndrome. Pain Physician. 2008;11(6):817-831.

37. Manchikanti L, Singh V, Falco FJE, Cash KA, Fellows B. Comparative outcomes of a 2-year follow-up of cervical medial branch blocks in management of chronic neck pain: a randomized, double-blind controlled trial. Pain Physician. 2010;13(5):437-450.

38. Manchikanti L, Singh V, Falco FJE, Cash KA, Pampati V. Evaluation of lumbar facet joint nerve blocks in managing chronic low back pain: a randomized, double-blind, controlled trial with a 2-year follow-up. Int J Med Sci. 2010;7(3):124-135.

39. Manchikanti L, Singh V, Falco FJE, Cash KA, Pampati V, Fellows B Comparative effectiveness of a one-year follow-up of thoracic medial branch blocks in management of chronic thoracic pain: a randomized, double-blind active controlled trial. Pain Physician. 2010;13(6): 535-548.

40. Tachihara H, Sekiguchi M, Kikuchi S, Konno S. Do corticosteroids produce additional benefit in nerve root infiltration for lumbar disc herniation? Spine (Phila Pa 1976). 2008;33(7):743-747.

41. Pasqualucci A. Experimental and clinical studies about the preemptive analgesia with local anesthetics. Possible reasons of the failure. Minerva Anestesiol. 1998;64(10):445-457.

42. Arner S, Lindblom U, Meyerson BA, Molander C. Prolonged relief of neuralgia after regional anesthetic block. A call for further experimental and systematic clinical studies. Pain. 1990;43(3): 287-297.

43. Sato C, Sakai A, Ikeda Y, Suzuki H, Sakamoto A. The prolonged analgesic effect of epidural ropivacaine in a rat model of neuropathic pain. Anesth Analg. 2008;106(1):313-320.

44. Byrod G, Otani K, Brisby H, Rydevik B, Olmarker K. Methylprednisolone reduces the early vascular permeability increase in spinal nerve roots induced by epidural nucleus pulposus application. J Orthop Res. 2000;18(6):983-987.

45. Lee HM, Weinstein JN, Meller ST, Hayashi N, Spratt KF, Gebhart GF. The role of steroids and their effects on phospholipase A2. An animal model of radiculopathy. Spine (Phila Pa 1976). 1998;23(11): 1191-1196.

46. Mao J, Chen LL. Systemic lidocaine for neuropathic pain relief. Pain. 2000;87(1):7-17.

47. Bisby MA. Inhibition of axonal transport in nerves chronically treated with local anesthetics. Exp Neurol. 1975;47(3):481-489.

48. Altman DG, Schulz KF, Moher D, et al. The revised CONSORT statement for reporting randomized trials: explanation and elaboration. Ann Intern Med. 2001;134(8):663-694.
49. Manchukonda R, Manchikanti KN, Cash KA, Pampati V, Manchikanti L. Facet joint pain in chronic spinal pain: an evaluation of prevalence and false-positive rate of diagnostic blocks. J Spinal Disord Tech. 2007;20(7):539-545.

50. Falco FJE, Erhart S, Wargo BW, et al. Systematic review of diagnostic utility and therapeutic effectiveness of cervical facet joint interventions. Pain Physician. 2009;12(2):323-344.

51. Cleland JA, Childs JD, Whitman JM. Psychometric properties of the Neck Disability Index and Numeric Pain Rating Scale in patients with mechanical neck pain. Arch Phys Med Rehabil. 2008;89(1):69-74.

52. Pietrobon R, Coeytaux RR, Carey TS, Richardson WJ, DeVellis RF Standard scales for measurement of functional outcome for cervical pain or dysfunction: a systematic review. Spine (Phila Pa 1976). 2002;27(5):515-522.

53. Vernon H, Mior S. The Neck Disability Index: a study of reliability and validity. J Manipulative Physiol Ther. 1991;14(7):409-415.

54. Manchikanti L, Hirsch JA, Smith HS. Evidence-based medicine, systematic reviews, and guidelines in interventional pain management: part 2: randomized controlled trials. Pain Physician. 2008;11(6): 717-773.

55. Manchikanti L, Benyamin RM, Helm S, Hirsch JA. Evidence-based medicine, systematic reviews, and guidelines in interventional pain management: part 3: systematic reviews and meta-analysis of randomized trials. Pain Physician. 2009;12(1):35-72.

56. Pereira J, Lawlor P, Vigano A, Dorgan M, Bruera E. Equianalgesic dose ratios for opioids. A critical review and proposals for long-term dosing. J Pain Symptom Manage. 2001;22(2):672-687.

57. Browner WS, Newman TB, Cummings SR, Hulley SB. Estimating sample size and power. In: Hulley SB, Cummings SR, Browner WS, Grady D, Hearst N, Newman TB, editors. Designing Clinical Research: An Epidemiologic Approach. 2nd ed. Philadelphia, PA: Lippincott, Williams and Wilkins; 2001.

58. Peloso PMJ, Gross A, Haines T, et al. Medicinal and injection therapies for mechanical neck disorders. Cochrane Database Syst Rev. 2007;3: CD000319.

59. Manchikanti L, Datta S, Gupta S, et al. A critical review of the American Pain Society clinical practice guidelines for interventional techniques. Part 2. Therapeutic interventions. Pain Physician. 2010;13(4): E215-E264.

60. Manchikanti L, Falco FJE, Boswell MV, Hirsch JA. Facts, fallacies, and politics of comparative effectiveness research: part 2. Implications for interventional pain management. Pain Physician. 2010;13(1): E55-E79.

61. Manchikanti L, Falco FJ, Benyamin RM, Helm S 2nd, Parr AT, Hirsch JA. The impact of comparative effectiveness research on interventional pain management: evolution from Medicare Modernization Act to Patient Protection and Affordable Care Act and the Patient-Centered Outcomes Research Institute. Pain Physician. 2011;14(3):E249-E282.

62. Manchikanti L, Falco FJE, Boswell MV, Hirsch JA. Facts, fallacies, and politics of comparative effectiveness research: part I. Basic considerations. Pain Physician. 2010;13(1):E23-E54.

63. Manchikanti L, Datta S, Derby R, Wolfer LR, Benyamin RM, Hirsch JA. A critical review of the American Pain Society clinical practice guidelines for interventional techniques: part 1. Diagnostic interventions. Pain Physician. 2010;13(3):E141-E174.

64. Hotopf M. The pragmatic randomized controlled trial. Adv Psychiatr Treat. 2002;8:326-333.

65. Tunis SR, Stryer DB, Clancy CM. Practical clinical trials. Increasing the value of clinical research for decision making in clinical and health policy. JAMA. 2003;290(12):1624-1632.

66. Roland $\mathrm{M}$, Torgerson DJ. What are pragmatic trials? $B M J$ 1998;316(7127):285.

67. International Conference on Harmonisation of Technical Requirements for Registration of Pharmaceuticals for Human Use. ICH Harmonised Tripartite Guideline. Choice of Control Group and Related Issues in Clinical Trials E10. July 20, 2000. http://www.ich.org/fileadmin/ Public_Web_Site/ICH_Products/Guidelines/Efficacy/E10/Step4/ E10_Guideline.pdf. 
68. Iversen T, Solberg T, Romner B, et al. Effect of caudal epidural steroid or saline injection in chronic lumbar radiculopathy: multicentre, blinded, randomised controlled trial. BMJ. 2011;343:d5278.

69. Carette S, Leclaire R, Marcoux S, et al. Epidural corticosteroid injections for sciatica due to herniated nucleus pulposus. $N$ Engl J Med. 1997;336(23):1634-1640.

70. Karppinen J, Malmivaara A, Kurunlahti M, et al. Periradicular infiltration for sciatica: a randomized controlled trial. Spine (Phila Pa 1976). 2001;26(9):1059-1067.

71. Manchikanti L, Giordano J, Fellows B, Hirsch JA. Placebo and nocebo in interventional pain management: a friend or a foe - or simply foes? Pain Physician. 2011;14(2):E157-175.

72. Manchikanti L, Singh V, Falco FJE, Cash KA, Fellows B. Cervical medial branch blocks for chronic cervical facet joint pain: a randomized double-blind, controlled trial with one-year follow-up. Spine (Phila Pa 1976). 2008;33(17):1813-1820.

73. Ghahreman A, Ferch R, Bogduk N. The efficacy of transforaminal injection of steroids for the treatment of lumbar radicular pain. Pain Med. 2010;11(8):1149-1168.
74. Chou R, Atlas SJ, Loeser JD, Rosenquist RW, Stanos SP. Guideline warfare over interventional therapies for low back pain: can we raise the level of discourse? J Pain. 2011;12(8):833-839.

75. Indahl A, Kaigle AM, Reikeräs O, Holm SH. Interaction between the porcine lumbar intervertebral disc, zygapophyseal joints, and paraspinal muscles. Spine (Phila Pa 1976). 1997;22(24):2834-2840.

76. Indahl A, Kaigle A, Reikeräs O, Holm S. Electromyographic response of the porcine multifidus musculature after nerve stimulation. Spine (Phila Pa 1976). 1995;20(24):2652-2658.

77. Pham Dang C, Lelong A, Guilley J, et al. Effect on neurostimulation of injectates used for perineural space expansion before placement of a stimulating catheter: normal saline versus dextrose 5\% in water. Reg Anesth Pain Med. 2009;34(5):398-403.

78. Tsui BC, Kropelin B, Ganapathy S, Finucane B. Dextrose 5\% in water: fluid medium maintaining electrical stimulation of peripheral nerve during stimulating catheter placement. Acta Anaesthesiol Scand. 2005;49(10):1562-1565.
Journal of Pain Research

\section{Publish your work in this journal}

The Journal of Pain Research is an international, peer-reviewed, open access, online journal that welcomes laboratory and clinical findings in the fields of pain research and the prevention and management of pain. Original research, reviews, symposium reports, hypothesis formation and commentaries are all considered for publication.

\section{Dovepress}

The manuscript management system is completely online and includes a very quick and fair peer-review system, which is all easy to use. Visit http://www.dovepress.com/testimonials.php to read real quotes from published authors. 